\title{
URBAN HERITAGE OF GRAMMICHELE AND LESSONS FOR MODERN CITIES
}

\author{
A.W. MUTIN \\ School of Design and Construction, Washington State University, USA.
}

\begin{abstract}
The paper discusses the morphology of a Sicilian town that was devastated by the earthquake of 1693 and rebuilt as idealized geometrical layout in accordance with Renaissance theories of the Ideal City. It briefly investigates Ideal City planning theories, social, economic conditions of Sicily underlying the reconstruction of the town, and analyzes the planning decisions that differentiated in their execution from the Ideal City principles, entailing questions of urban density, the visual power of building form, and futuristic planning, that could serve as a lesson of a well-designed model community for the Modern Age.

Keywords: Architecture, community, earthquake, environment, innovations, topography, urban design.
\end{abstract}

\section{INTRODUCTION}

In January 1693, a powerful earthquake struck the Noto Valley in the southeastern region of Sicily. Nearly 40 towns were partially or entirely destroyed; among which was Occhiola, small town of few thousand inhabitants. Occhiola was situated inland from the coast at the foothills of the mountains. The devastation was of such severity that preservation and rebuilding were not considered. New, safer location was chosen in the neighboring proximity of the original town, on land as level as the topography allowed. Soon the new town of Grammichele rose in the vicinity of Occhiola. The initiative, financing, and conceptual planning for the town was initiated by Carlo Maria Carafa Branciforte, the landlord of Occhiola and neighboring lands, oversaw the planning of Grammichele, the plan was prepared by Michele de Ferla, a Jesuit priest. The plan adhered in principle to the Renaissance theories of the Ideal City, characterized by ordered polygonal layouts. Grammichele, however, was conceptually inventive, developing those principles in innovative arrangements. The new town adhered to the functional demands of its agrarian economy and peasant populace, and was plain in appearance.

\section{INFLUENTIAL PRECEDENTS IN THE PLANNING OF GRAMMICHELE}

The 16th century European Renaissance broadened the scope of intellectual exploration and its root in the antiquity awakening an interest in societal change and utopian forms of living. Influential books written in 1500s and early 1600s: a treatise The Truly Golden Book About the Best Condition of a Commonwealth and About the New Island of Utopia by Thomas More, City of the Sun by Tommaso Campanella [1,2] and The New Atlantis by Francis Bacon [3] laid ground for the discourse on utopian forms of living and new ideally designed cities.

The design of new cities was closely related to the advancement in military fortifications that in turn related to the evolution in the arts of war. Those new protective enclosures were represented by polygons with projectiles whose geometric construct often began with a circle, a figure of smallest perimeter, into which squares rotated by $30^{\circ}$ or $45^{\circ}$ to one another were written forming a figure with star-like projectiles. Those forms served as a base for design of fortifications and in time for a plan of a town within. Filarete, Alberti, Scamozzi, Serlio, and Cataneo [4] influenced by Renaissance spatial theories proposed plans of cities as pentagons, hexagons, octagons, 9, and 12-sided polygons. The enclosure provided defense, whereas interior layout reflected two organizational principles one of a grid and the other radial. In first, into a polygon square or rectangular grid of streets and blocks 
was written, the second followed radial distribution of streets and blocks. Cataneo's plans reflected first arrangement [5] and Filarete in design of Sforzinda proposed radial street layout [6]. Theoretical plans influenced built examples: residential Karlovac (1575) and city garrison of Palmanova (1597) [7-9] parallel in execution to Grammichele (and Avola) the town of New Brisach (1697) and later Hammina (Finland 1723), which reflect these organizational principles.

Karlovac and New Brisach featured grid layouts, whereas Palmanova and Hamina's plans were radial. Among them only Karlovac and Palmanova were built before Grammichele (Fig. 1). Grammichele's plan represented radial typology without fortifications town perimeter that met the fields.

Sicily was a fertile ground for innovation. Several new towns were built during the 1600s in Sicily: among them San Stefano di Camastra (1668) (Fig. 2) Avola, Grammichele and Noto (1693) demonstrated the presence of high-level creative activities.

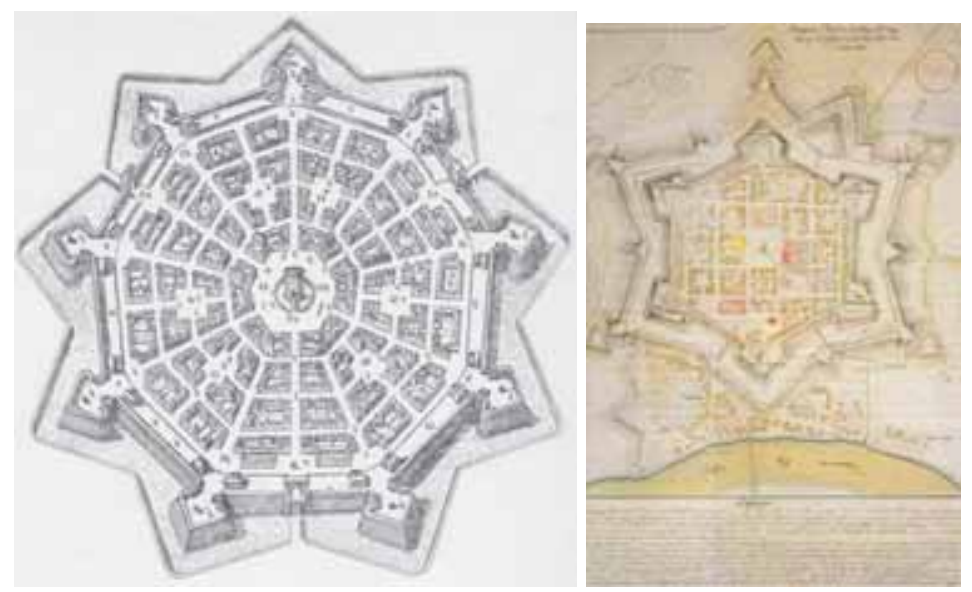

Figure 1: Palmanova and Karlovac, built according to Ideal City principles.

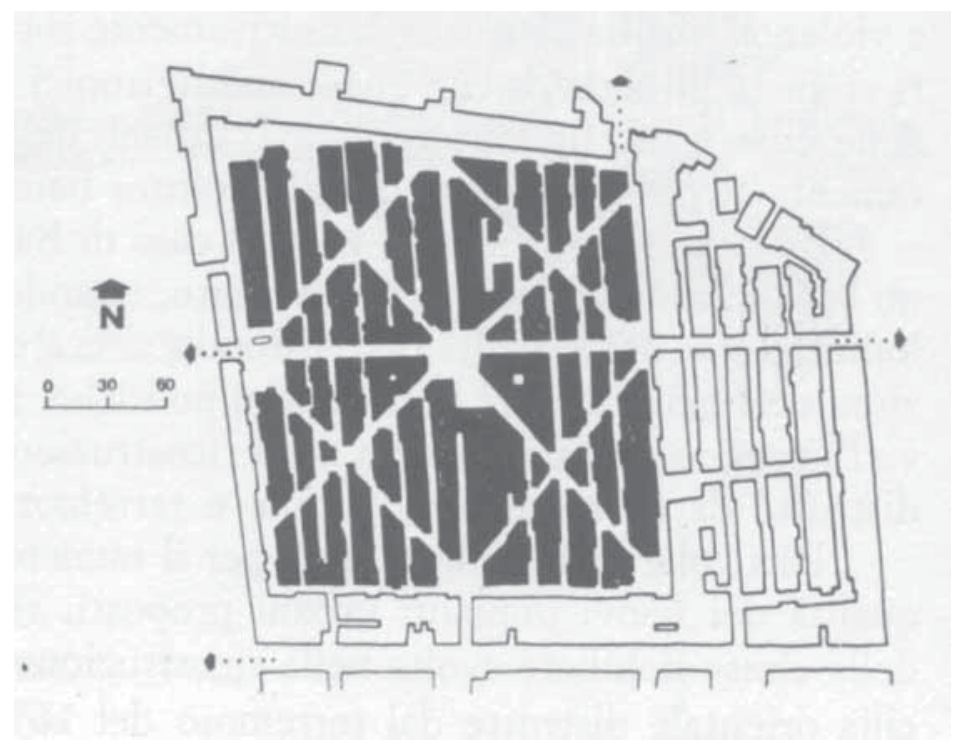

Figure 2: Plan of San Stefano di Camastra (1668) from Sicilia Barocca by Salvatore Boscarino. 
San Stefano di Camastra replaced buried by the landslide town of San Stefano. The plan was conceived soon after rectilinear grid towns of Bolognetta (1610), Ventimiglia (1625), and Aliminusa (1635). The town layout is very unusual, defined by two intersecting geometries. Narrow blocks of south-north orientation are bisected at an angle by east-west-oriented streets forming rhomboidal superblocks with triangular blocks at the perimeter. There were five open spaces within the plan: one at the center and four axially positioned at the perimeter [10].

Maria Giuffre in Utopie Urbane Nella Sicilia Dell 700's [11] discusses in broader scope Sicilian urban utopias. In writing about Grammichele Giuffre is not engaging in the analysis of the plan, and is not discussing the differences between the plan and the Ideal City theories. In Miti e Realta dell' Urbanistica Siciliana; Contributo alla storia dell' Isola dall Cinquecento ad Oggi there is no further clarification. Salvatore Boscarino in Sicilia Barocca Architettura e Citta discusses Grammichele plan briefly, points to the existence of the residential boroughs and five open radial streets the sixth arrested by the princely residence concluding plan analysis [13].

\section{ANALYSIS OF THE ORIGINAL PLAN OF GRAMMICHELE}

The planning of Grammichele is a unique urban phenomenon. The plan reflects theories and planning principles of Ideal City, and it introduces design innovations that set it apart from the theoretical and built examples. Observations outlined here are based on two existing plans: one drawn on the piece of gray slate by Michele da Ferla under the auspices of Carlo Maria Carafa Branciforte Prince di Butera, immediately after the earthquake, the other a three-dimensional representation, painted at a later date on the wall of reception rooms in Butera Palace in Palermo, on Prince di Butera correspondence deposited in State Archives in Palermo and more recent publications.

Prince di Butera feud and town of Occhiola were situated in the remote, mountainous, sparsely populated region of Sicily. Occhiola was inhabited by peasants who were poor. The town did not possess visual power that new community would have to imitate. Organizational simplicity and lowkey imagery appeared to be a conscious factor in planning of Grammichele.

It was suggested that plan of Palmanova (1593) influenced the design of Grammichele [14]. This, in my opinion, is not correct. The only known plan of Palmanova by M. Dogen was published in 1647, a nine-sided polygon with hexagonal open space, of substantial inner complexity only superficially in my opinion, resembling Grammichele. Palmanova and Grammichele are polygons with radial distribution of streets, both have polygonal open spaces at the center, and here similarity between them ends. In Palmanova the importance was placed on the defensive town character. Only 3 out of 18 radial streets connect gates with center of the town, the other 3 connect center with defensive bastions. Out of the remaining 12 streets, 6 bypass interim open spaces halfway into the town to terminate at the wall of buildings that enclose hexagonal plaza at town center, whereas the remaining 6 terminate at the prow of same building wall trapping potential intruders. Palmanova was a military fort enclosed by fortifications.

By contrast, the plan of Grammichele abandons spatial complexity in favor of axial clarity. A hexagon formed of streets and blocks emanating in radial fashion from the hexagonal open space becomes the core of town. To this six boroughs are affixed. Princely borough including prince's residence overlooking an open space is placed at head of composition, arresting one of six axes of the town. All axial streets connect Grammichele's perimeter with its center. Grammichele had no wall drawn or erected at its perimeter (Fig. 3).

The formality of a hexagon with boroughs attached reminds of the emperor Trajan's Portus in Ostria Antica, an arrangement of buildings surrounding hexagonal port. Six sides of the Portus are lined with identical buildings but one allows the water in. In Grammichele's plan, six boroughs are 

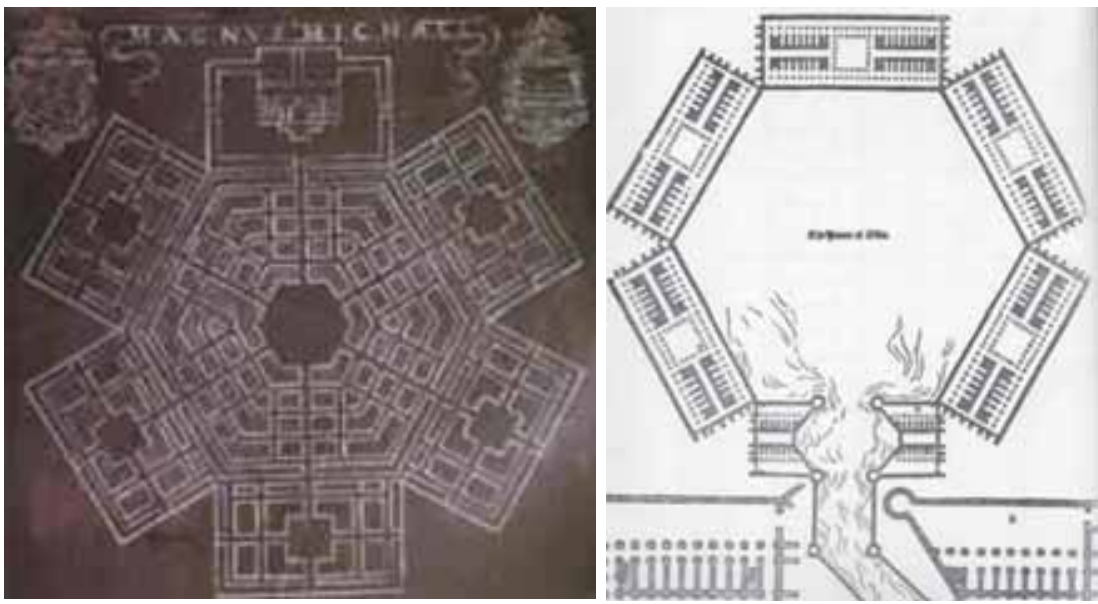

Figure 3: Plan of Grammichele (Michele da Ferla 1693) and Trajan’s Portus (Serlio 1573).

attached to the hexagonal core, but one, princely borough is different. Functional designation differs but the concept of a hexagon with appendices is similar [15].

According to Giovanni Gianformaggio prince Carafa designed the plan himself 'la pianta di quale, ideata e designata dal principe stesso, fu intagliata sopra una lastra di lavagna da un fra Michele da Ferla, della Riforma de' Minori Osservanti, esimo architetto, che n'esegui anche il tracciato sul terreno'[16]. This engraving is displayed on the stairway wall in Grammichele's Palazzo Municipale.

Da Ferla's engraving is a formal representation of great simplicity. The princely borough is placed at the head of composition, whereas the remaining five designated as residential follow. Princely borough is not aligned with geographical north stressing formal elegance of the plan.

Second plan of Grammichele painted on the wall in reception room of Palazzo Butera in Palermo a century later provides additional information (Fig. 4). Its orientation differs from da Ferla's plan the princely borough is rotated $60^{\circ}$ to the west but position of boroughs, blocks and open spaces remains unchanged. Graphic representation differs painting is three-dimensional suggesting heights of the buildings by the shadows they cast. All inner blocks with the exception of a narrow perimeter block, feature courtyards. That fact provides an insight into housing arrangement.

Grammichele's hexagonal nucleus stops at the perimeter block to which all boroughs are affixed. Five boroughs feature dimensionally identical squares at the center, whereas square in the princely borough is larger.

The influence of Palmanova is seen in resolution of Piazza Carafa whose corners are formed by meeting at angular buildings with the exception of Il Duomo. Radial streets penetrate building walls of hexagon at center, thus defining six sectors (from street leading to former princely borough clockwise): San Michele, San Carlo, Santa Caterina, L'Annunziata, San Rocco, and L'Angelo Custode. Il Duomo, Municipal Palace, and Theater face Piazza Carafa that serves as a functional and ceremonial center of the town.

Residential character of Grammichele is reflected in width of blocks, hierarchy of streets, and open spaces (Fig. 5). In metric system, the radius of Piazza Carafa, tangent to the building wall measures $53.5 \mathrm{~m}$, first four blocks approach $20 \mathrm{~m}$ in width each, perimeter block nears $12 \mathrm{~m}(12,12.6$, 13.4 , and $13.5 \mathrm{~m}$ ). Radial streets are $10 \mathrm{~m}$ wide, whereas secondary are $8 \mathrm{~m}$ wide. Via Crispi, continuous and circumferential today, connecting boroughs measures $10 \mathrm{~m}$. 


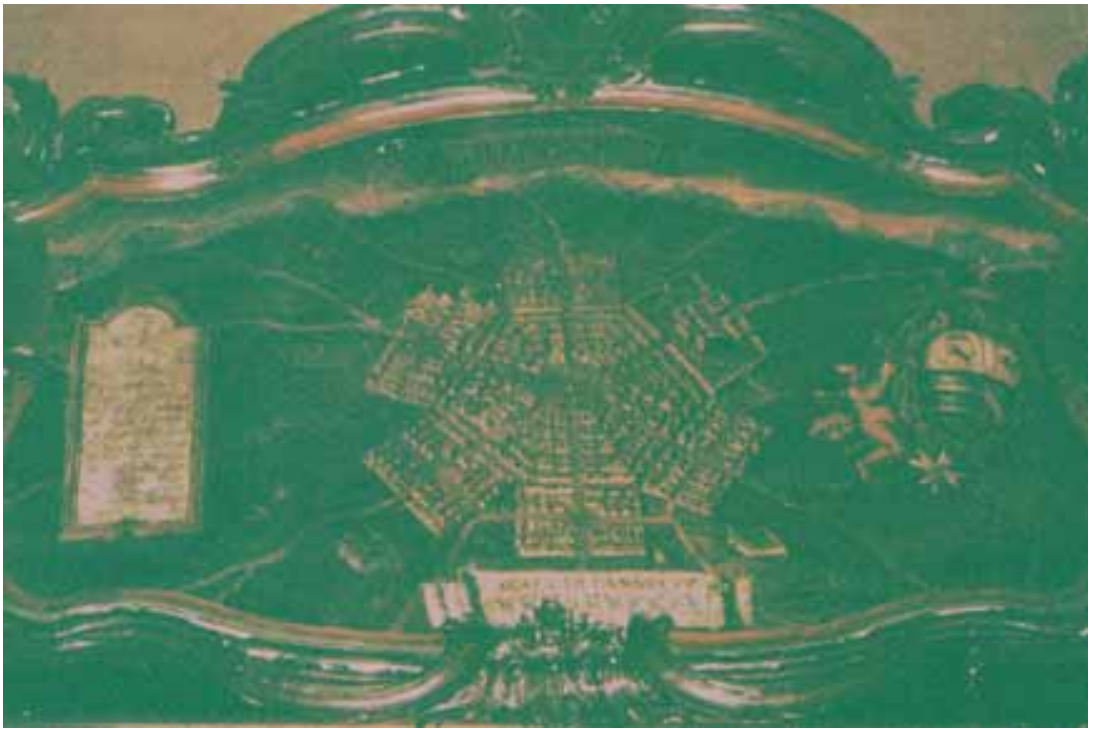

Figure 4: Plan of Grammichele painted on the wall of reception room in Palazzo Butera.

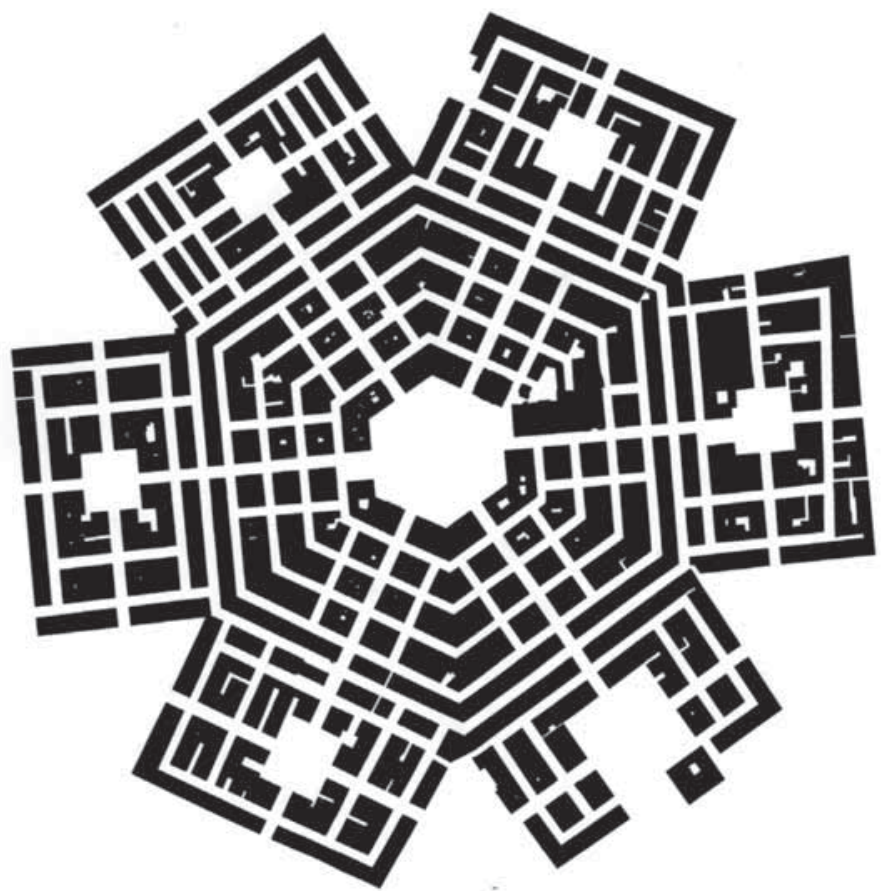

Figure 5: Figure ground of Grammichele based on recent documentation. 
It appears that radius of Piazza Carafa served as a module to locate center of boroughs and their squares. The radius of $53.53 \mathrm{~m}$ multiplied by 5 is $267.65 \mathrm{~m}$, a dimension that approximates measurements taken from center of town to center of boroughs: of 264.0, 265.85, and $265.43 \mathrm{~m}$. This difference explains irregularities of block width within the boroughs that are: block next to the perimeter: $14.9,14.7 \mathrm{~m}$, remaining blocks are 21.0 , and $21.5 \mathrm{~m}$ in width. Open spaces are $45.5 \times$ $46.5 \mathrm{~m}$ approximately each, princely borough is $80 \times 80 \mathrm{~m}$. Rectangular boroughs appear to be constructed according to the principles of golden section.

Grammichele blocks were narrow. In da Ferla's plan, the blocks had no courtyards but Da Ferla's drawing is a concept of town, not a detailed plan. Painting in Palazzo Butera features courtyards within the blocks. Judging by those plans, Grammichele's houses were either $6 \mathrm{~m}$ (with courtyard) or $10 \mathrm{~m}$ deep within the blocks (20-m wide) and shared two or three walls with the adjoining party windows faced courtyard and street or only the street. Considering depth, width, and height of two floors, gross area had to be between 70 and $200 \mathrm{~m}^{2}$.

Town blocks, given hexagonal layout were of increasing length. To break this length and ease pedestrian movement cross streets were introduced. They are equivalent in length to three inner blocks including two streets in between, a total of $72 \mathrm{~m}$, running from block enclosing Piazza Carafa to the perimeter block. There buildings arrest street views on both ends, open vistas were found only at radial streets.

Question arises where this spatial efficiency comes from? Was it influenced by densely built Occhiola and other Sicilian hill towns or directed by monetary constraints? Pedestrian quality of town benefits from close proximities, but pedestrian quality was de rigueur at that time. To a modern visitor Grammichele is a lesson in density. Nearly 18,000 people live in an area smaller than $10,000 \mathrm{~m}^{2}$ in buildings of average height of two to three floors. One cannot but question why the plan was so efficient, so clear, and so tight?

Architectural character, judging by preserved structures, was of remarkable uniformity. Buildings in sectors $f$ and $a$, and $a$ and $b$ even with later additions, portray similar distribution of ground floor openings and upper floor windows. Articulation of Piazza Carafa architecture is similar: pilasters, resolution of corners, friezes and even building height, observed in residential building of statue in sector $e$ reveal similar articulation. By keeping articulation uniform, the emphasis was placed on public buildings and Il Duomo.

Lesser degree of control was exercised in articulation of residential buildings along Corso Emanuele whose eloquence of expression is explained by their later date. Residential scale of town is maintained at one, two and in few cases three storey's.

At present there are six churches all within the boroughs, at or in the proximity of residential squares: Church of San Giuseppe siding Piazza Dante, square of princely palace, Church of Santa Anna in Santa Caterina sector, block from Piazza Vespri, Church of Santo Spirito in the sector of San Rocco, siding Piazza XX Settembre and San Leonardo adjacent to Il Duomo - all face radial streets. The sixth church of San Rocco stands in green space that once existed between residential boroughs in Largo Occhiola, outside of the original plan.

Churches play an important role in Sicilian town life frequented daily. During religious holidays, churches are a part of celebratory processions. Those festivities engage the entire town population, follow different route bypassing parts of town. Angela Guidoni Marino describes in detail each of those trajectories [17].

Town geometry not always adjusts well to fluctuating topography. Most level part is near Piazza Carafa and in southern half of the town. Near northern perimeter the land slopes gently then drops substantially, its fluctuation most evident in sectors of San Rocco and Angelo Custode, where streets rise and fall from $1 \mathrm{~m}$ to $3 \mathrm{~m}$. In square Giovanni Meli greater difference allows for radial Corso 

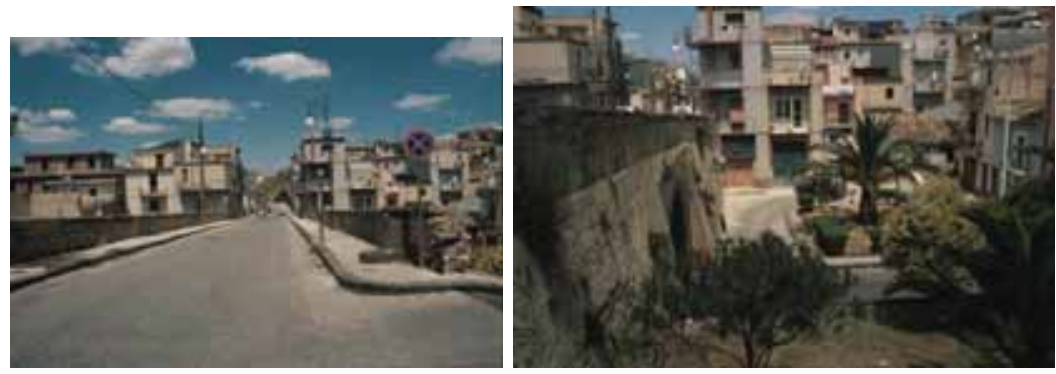

Figure 6: Spatial configuration of Piazza Meli.

Cavour to bi-pass, over circumferential Via Crispi (Fig. 6). In effect Giovanni Meli is divided into two rectangular spaces but formality of the plan remains intact.

\section{URBAN STRUCTURE OF GRAMMICHELE TODAY}

On eastern approach road follows moderate rise. Etna dominates the northern view distant hills south and west. Orange groves and cultivated fields cover the ground until ravines start to carve the land allowing only grasses and olive trees to grow. Farmhouses and few commercial buildings dot the land. As the road steepens, the view opens to the distant sea, ravines grow deeper, grasses and brush denser wilderness overwhelms the land. Closer farmhouses appear and suddenly the edge of the town becomes visible.

Approach from the south differs. The road first steps up onto a plain overlooking the sea, then begins to follows ridges of frequent ravines bypassing or overlooking ridge of the towns. Landscape is beautiful, and wild. First view of Grammichele is an anticlimax of sorts, few loosely scattered buildings then standing higher above the road - stands the town (Fig. 7).

The town is orderly and quiet. Streets and blocks line up in succession, their rhythm arrested by the square resumes to arrive at a vast hexagonal space, then it repeats itself to arrive at another square before entering the fields again. The scale is intimate, conquerable quickly. The orderliness of Grammichele is visible in clarity of plan, spatial organization see through transparency that allows for open vistas toward the landscape and sky beyond and uniformity of architecture with its relationship to streets and open spaces. In contrast to organically built Sicilian hill towns, this formally planned, controlled urban environment is very soothing.

The original plan of Grammichele remains largely intact but it remains buried in later day development. Town expanded by 2, 3 and up to 20 blocks especially in southeastern direction where land slops gently and business and residences line up along Corso Vittorio Emanuele that connects Piazza Carafa with the railroad station.

Topographical fluctuations on northeastern edge of the town prevented expansion (Fig. 8). Relationship between building height and width of streets and open spaces remains largely unchanged with the exception of Piazza Dante (former princely borough). Majority of the buildings are one and two storey's high with the exception of radial streets and squares with three-storey structures. There is one five-storey building on Piazza Dante with last floor set back to reduce its impact on spatial quality of the square. Piazza Carafa remains the heart of the town (Fig. 9), baroque Il Duomo stands next to the 19th century Palazzo Municipale, across from a Theater building. Il Duomo and Palazzo Municipale dominate the piazza. Il Duomo is a work of Antonio Amato [18].

Palazzo Municipale, second in importance among the buildings of Piazza Carafa replaced Palazzo dei Giurati, the work of Capo Mastro Onofrio Grosso. Palazzo dei Giurati was a two-storey structure 


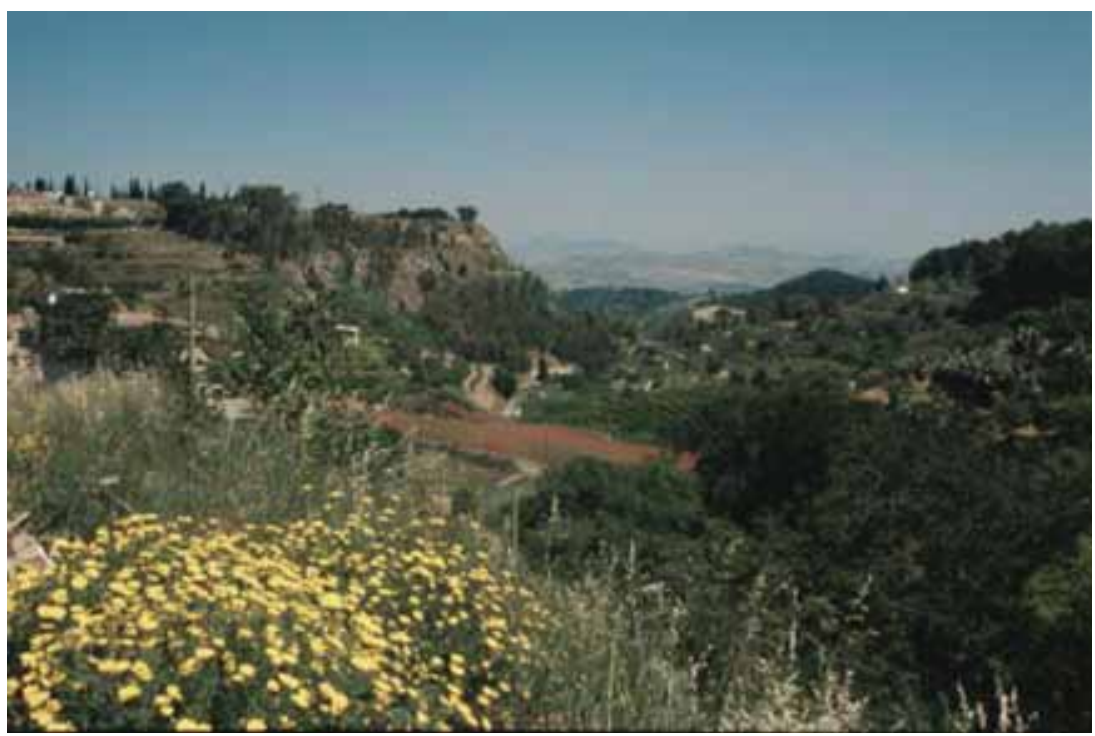

Figure 7: Approach to Grammichele from the south.

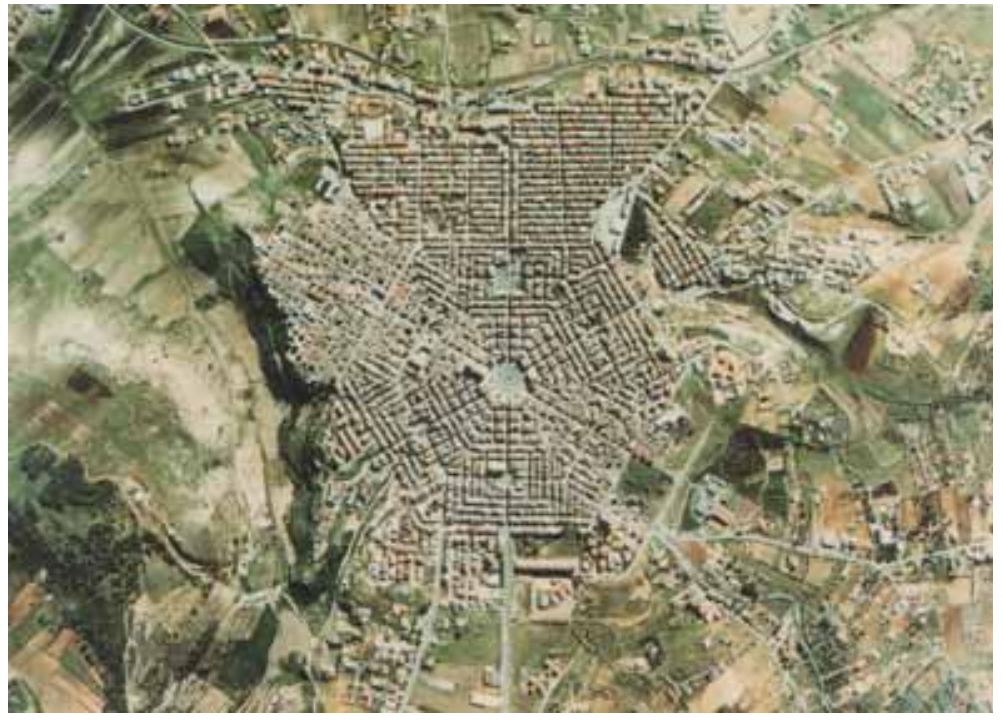

Figure 8: Grammichele as viewed from the air (from a postcard).

topped by a one-storey balustrade and related well to other buildings. Its replacement, Palazzo Municipale built (1896 architect Carlo Sada) upset this balance. The building is lower from sky aspiring Il Duomo façade, but its bulk coexists uneasily with the church and adjacent buildings, spoiling its spatial unity. Residential buildings of note serve as banks, pastry shops and restaurants. Usually two- and three-storey's in height and understated articulation they support somber grandeur of an old palatial building occupied by Banco di Sicilia. Center of farming community, Piazza Carafa 

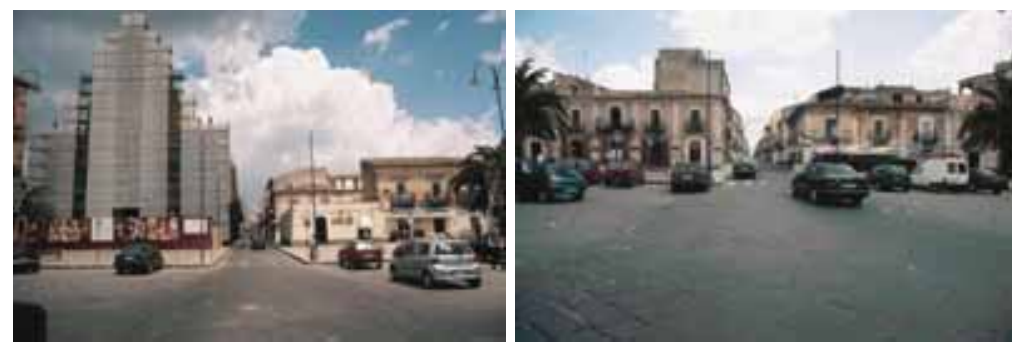

Figure 9: Two views of Piazza Carafa.

served religious, civic and business functions, that tradition is preserved today. Buildings lining radial streets, (Corso Vittorio Emanuele) display richness of articulation. The resolution of facades reflects 19th-century convention of décor; entries, windows, and balconies are ornamental. Articulation addresses functions - ground floor of commercial designation and residential floors above. Treatment of the second floor reveals the importance of the owner in town hierarchy. Residences along side streets are simpler. Spatial unity and respect to historical envelope of town is owed to the efforts of town architects under the direction of Giovanna Cimino.

Piazza Carafa an open space of great dimensions $(100 \mathrm{~m})$ reflects public functions (Fig. 10). Vehicular traffic and parking are separated from pedestrian zone where cafes, patisseries, and bars proliferate. There was a weak attempt to landscape the piazza by planting palm trees. Palms are not addressing public needs by casting shade. Those shortcomings were reflected in (1998) competition for the resolution of Piazza Carafa. The winners were chosen but realization is slow in coming.

Squares in residential boroughs retain their spatial quality. Their unique characteristic aspect lies in solid corners. In few instances the corners are broken by passages leading into the block. Squares are subdivided into quadrants by streets. The quadrants are planted with grass, olive and pine trees and defined by low walls. Few benches exist. Steps negotiate level fluctuation in some of the quadrants. Most of the architecture is of later date. The prevalent number of floors remains between two and three storeys.

Spatial anomaly caused by the topography exists in Piazza Meli, formally a square. Several meters in height separate radial Corso Cavour from circumferential Via Crispi: Corso passes over Via Crispi in the form of a bridge. Piazza Meli buildings remain at the level of Via Crispi effectively dividing the square into two rectangular spaces and a sloping floor.

The elegance and clarity of Grammichele's original plan is buried to a degree in new development. Residential boroughs grew, green spaces between them filled up, forming today's Largos that feature: a park, a modern plaza and a playground.

Largos differ from symmetrical residential squares, are irregular and relate to Via Crispi. Largo Occhiola situated on the outer side of Via Crispi is a dynamic urban space animated by the streets and a church of San Rocco, its pivotal tour de force (Fig. 11). The church is placed at an angle to Via Crispi, subdividing the Largo into residential and public realms. Age of residential architecture varies. On town side of Via Crispi are two older buildings two storey's high another stands to Largo's left side along the street flanking the church. Remaining buildings are more recent two- to threestorey high. Within the Largo, Via Crispi drops $3 \mathrm{~m}$ on its way to Piazza Meli affecting Largo's character.

Cammara is on the town side of Via Crispi also affected by level differentiation. Camarra's shape is trapezoidal outlined by streets with garden that serves as a playground, semi-private in character. 


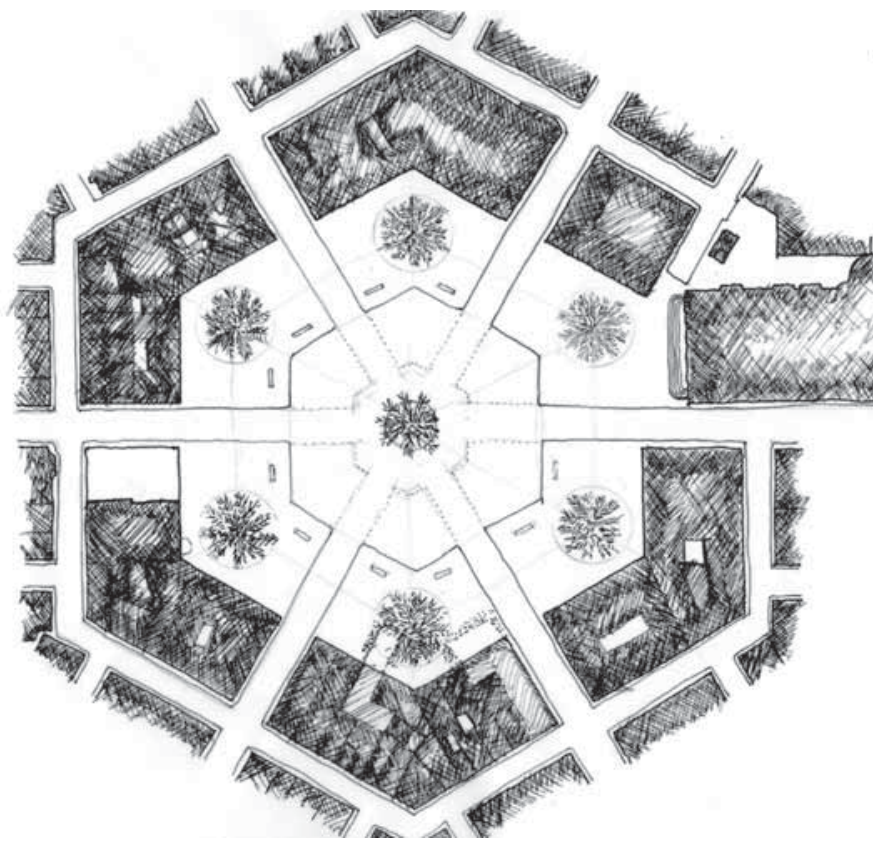

Figure 10: Present day resolution of Piazza Carafa.
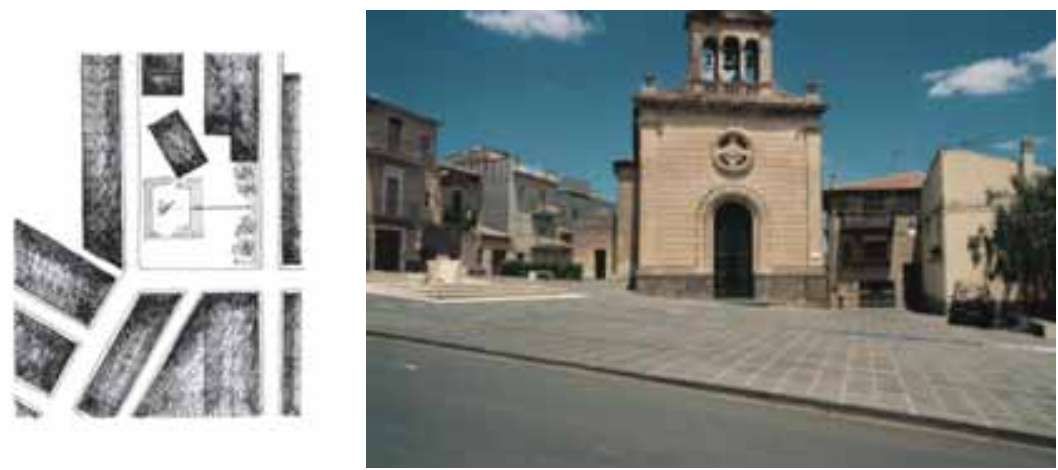

Figure 11: Plan of Largo Occhiola and view of Church of San Rocco.

The buildings are two and three storey's, one four-storey high stands in the lower section but spatially relates to remaining structures. Older structures tend to line up Via Crispi.

Piazza Marconi is placed on the outside side of Via Crispi. Piazza and its garden serve Ospedale Civico 'Barbuzza' and Church dell'Immacolata. Both buildings are older remaining architecture is of later date and height of two to three floors.

Piazza Morello located at the end of radial Corso Roma now arrests the only axis in town, a result of later expansion (Fig. 12). Church, library, and residences line its sides. In the approach to Piazza Morello, Corso Roma rises up its visual perception augmented by the placement of buildings arresting the axis on podium. Elevating the buildings (church) and then shifting it away from the axis 


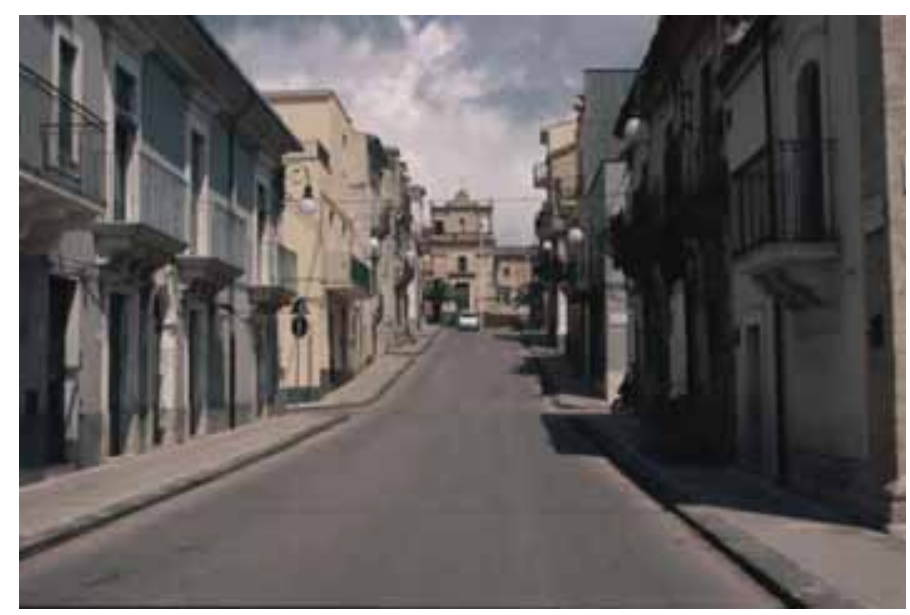

Figure 12: Corso Roma leading to Piazza Morello.

suggests the presence of perpendicular street, a sophisticated urban move. Placing a church on street level would diminish its visual dominance on leading to its street.

Town functions are well-defined. Almost all businesses, shops, and eateries dwell on Piazza Carafa and radial streets, defining their role as public. Among the squares Piazza Dante and Piazza XX Settembre feature shops and a gas station each, designated as public, others remain residential. Circumferential streets are residential and semipublic in use.

\section{PLANNING INNOVATIONS OF GRAMMICHELE}

The plan for Grammichele was drawn soon after the earthquake, how soon it is not known. Considering urgent need of stricken population, its swift preparation was necessary. Yet the apparent ease with which a plan of such design sophistication was drawn may indicate that a concept of it was nurtured before the earthquake.

Seven planning innovations defined the plan:

1. Attachment of boroughs to hexagonal core. Social and spatial hierarchy

2. Defining desirable size of town. Plan anchored in natural landscape

3. Openness and transparency along the axes

4. Polygonal plan not enclosed by military fortifications

5. Planned density of town

6. Proportion of mass to open space

7. Polygonal plan set in fluctuating topography

First of those is the attachment of boroughs to hexagonal core. In da Ferla's plan the princely borough is set at the head of composition reinforced by axially placed Prince di Butera palace, stressing its formal role. Remaining boroughs treated identically were defined as residential. This resulted in elegant symmetrical plan with clearly defined hierarchy of uses in which public activities reside in the heart of town.

Prince di Butera passed away 2 years after the earthquake and the palace was never built. This is unfortunate. If the palace was realized and if the prince came to reside in this town, even temporarily, 
Grammichele would had developed differently. Prince's entourage, nobility, clergy, and merchants would erect residence and civic buildings, enriching town life and activities provoking richer exchange. Social, ceremonial, and economic aspect of town's existence would have been transformed.

Arresting hexagonal core to the depth of four blocks and allowing nature to separate the attached boroughs represent second planning innovation. By doing so desirable size of the community was defined.

Maintaining town visual transparency would be a third innovation. Five of the six radial streets were left open, not arrested by gates or walls, allowing see through experience from fields to fields. Radial streets allowed also the winds to enter town and open it to views and beyond.

Fourth decision is seen in apparent absence of military fortifications. Theoretical polygonal planning was associated with, and resulted from military fortifications. Sicily at the end of 17 th century was a peaceful country not like other parts of Europe and remotely located Grammichele had more immediate concerns. Instead of fortifications L-shaped blocks enclosed the boroughs. Faint line drawn across the axes in da Ferla plan suggested a portal of a sort. Fortifications were not drawn. Whatever reason prevailed, location or monetary constraints Grammichele represents a polygonal plan without military fortifications.

Fifth decision was to prepare a plan for a larger then needed community of remarkable inner density. This proposition could follow the precedent of tightly knit densely built Sicilian hill towns or respect monetary constraints but it could as well be a desired planning factor. This factor especially becomes apparent when city as planned is compared with the number of earthquake survivors. Its predecessor Occhiola, numbered just under 3000 people, a modest amount. Considering number of fatalities, which amounted to half of the population, Grammichele had to provide dwellings for 1500 people, with adjustment for future growth possibly a double of that, 3000 people. Judging by today's number of 18,000 people, the plan as drawn was capable to accommodate 9000 .

Building height and its relationship to the width of streets represent sixth planning decision. Average building height was two storey's, a $7 \mathrm{~m}$ to maximum of $10 \mathrm{~m}$. Principal streets were $10 \mathrm{~m}$, and side streets were $8 \mathrm{~m}$, reflecting rules set after the earthquake that required streets and open spaces to accommodate town population. Visual dominance of churches was thus addressed.

Seventh decision must have occurred between execution of the concept and its implementation, when a plan suitable for level location was laid out on topographically fluctuating terrain. Flat portion of Gran Michele property was smaller than the town measurements. The town was platted without the adjustments to fluctuating topography as seen in Piazza Giovanni Meli and adjacent streets.

Formal plan of Grammichele stressed societal structure and defined hierarchy of uses: seat of power and dwellings for subordinates, civic and residential, public and semipublic. Thus, defined organization responds well to the image of model community in which clarity of social structure would facilitate town functioning and interaction.

Grammichele was traversed on foot at a leisurely pace in less than 10 min. Plan centrality facilitated movement to and from the fields and around the town. The hexagonal nucleus of Grammichele is barely more than $345 \mathrm{~m}$ wide and with boroughs attached to it increases to about $635 \mathrm{~m}$.

Grammichele has all the essential ingredients of a model community: an elegant symmetry, an efficient interior organization, simplicity and openness, and equal treatment of residential streets and blocks.

It appears that the town was designed to make people feel equal under protection of the lord, enforced by plan representation. Given this Grammichele could be a model town. If it was so, splendor and pageantry had no importance, and it was not enforced in the plan. Narrow blocks limited type of residential architecture and discouraged other uses. If one considers the speed in 
which the plan was conceived, the idea that such a plan existed before the disaster is not impossible. Question is to what a degree Grammichele was an achievement of idealistic ideas and fulfillment of the dream to create a model agrarian community?

\section{CONCLUSION: A LESSON FOR THE MODERN AGE}

Grammichele was and is in many ways a unique answer to provide comfortable low-rise highdensity living environment for its population.

Previous section discussed seven planning innovations distinguishing Grammichele from theoretical proposals and realizations of Ideal City. But in more specific terms as an influential example of planning and of interest to this study Grammichele also addressed interrelated design issues that are as important to a well-designed and functioning Modern Age town as they were at the end of 17 th century.

Those issues are:

1. Definition of hierarchy of uses: public, semipublic, semiprivate - streets and open spaces. Clarity between these hierarchies helped the town citizens to recognize defined community and private boundaries, and thus, interact with the necessary functions of the town accordingly.

2. Differentiation between principal and secondary open spaces serving gathering/green functions in the city. This was achieved by centrally positioned large public square that served for civic and ceremonial functions of the city. Smaller in size residential squares were placed at the center of residential boroughs and of equal distance to large public square and the center of town activities.

3. Distribution of functions: public in support of residential. Public functions in squares and radial streets enhanced the social and economic dynamics of the city.

4. Importance of human interaction. Evidenced by central public square - equivalent of a modern agora, residential squares and wide principal radial streets all facilitated human interaction.

5. Establishment of desired density reflected by anchoring the town in natural landscape to arrest the growth of central hexagonal core and define desired size of the community. Density related and facilitated by the efficient distribution of residential building blocks. Architectural envelope of tightly knit two-storey buildings placed in well-defined blocks provides an example of sensitive economy of design in low-rise resolution. Additionally residential structures of $7 \mathrm{~m}$ in height would cast in this geographic location relatively small shadow resulting in dense yet livable community.

6. Regulation of building envelope. Low-rise two-storey high-residential architecture had an unexpected impact on city aesthetic. Low structures gave importance to the public buildings allowing them to stand out from the mass and be seen from a distance, especially all of the town churches most of which were located in the proximity to residential squares with the exception of placed in the center of town Il Duomo.

7. Controlled clear geometry of the plan that allows the above-mentioned design principles to take place and rendered town circulation clear and legible.

Looking at the design examples and implementations of new towns through the history: centralized planning mandala's in what is today India, Middle-Age Bastides in France and Wales, Terra Muratas in Florentine Republic, Ideal Cities of the Renaissance and Baroque, working city of Salines de Chaux, or emerging during the industrial age company towns, one observes the desire to provide a well-organized, working city plan in which required functions find their place to serve the population: residential, commercial, and working environment or military needs. Not always this may be said of the quality in which city's organizational, spatial, and political hierarchy was 
resolved. In more specific terms the differentiation between public, semipublic, semiprivate street or placement of the public space and its function at the heart of community was addressed to a lesser degree in the Bastides, some of the Terra Murata's and in most of the Ideal City plans.

Importantly there was a question of how to utilize available land to achieve maximum density while retaining other design requirements. Medieval Bastides, and Terra Muratas were planned for a population of below or around 2000 people, most of the built Ideal Cities accommodated same or at best double of that number, 2000-4000 people, similar number of residents were associated with the Industrial Age company towns. Grammichele it appears was designed for around 9000 people, which represents a large number by comparison.

During the 20th century rethinking of the concept of what a new town or a city should be evolved further often addressing specific concerns: new developments at the turn of 20th century were responding to the requirements of the garden city movement, during the decades between two World Wars and in the two decades thereafter, buildings were freed from the layout of the streets and placed in park-like setting, in which if possible or even specifically (Radburn) a thorough separation of pedestrian and vehicular movement were initiated.

The architects and planners in the democracies of the United States, France, England, India, Brazil, Israel, and Australia and in totalitarian regimes of Germany, Poland, and Soviet Union not always successfully designed and built new cities. Some of these were small towns but more frequently design called for a larger city able to accommodate tens of thousands of people, or even, designed to serve as the capital of the country. Urban theories of Perret, Le Corbusier Hilbersheimer, Frank Lloyd Wright, Costa, or smaller scale of special concern proposals and realizations of Ebenezer Howard, garden apartment evolution in Europe and the United States, Clarence Stein and Henry Wright solution for Radburn at Fair Lawn, NJ, Mies's van der Rohe Weisenhoffsiedlung designed under the auspices of Werkbundsiedlung and others, addressed modern issues.

Some of the theoretical proposals and influenced by them realizations proved not to work that well. Auguste Perret formulated the principles of Tower City 1920-1922 and Le Corbusier designed City of Towers 1921 proposing rhythmic distribution of tall buildings (in Le Corbusier case) placed amidst gardens and playing fields with low-rise structures situated in the adjacent blocks [19]. Those ideas exerted wide influence on up-coming urban design. While appealing in principle situating buildings in landscape to turn open land for recreational use (yet achieving high density), the proposals eliminated traditional street layout replacing it with a square grid of roads in which primary function was given to the automobile not to the pedestrian movement. This created an altogether uninviting environment to commercial and cultural functions to participate in street life as a part of a whole and not as an entity apart from the whole. The street as we know it ceased to exist. Buildings placed in the landscape and at a distance from the street created empty, robbed of life street environment in which the exchange between the people coming and going to residences, offices, commercial establishments, or cultural institutions were replaced by cars. Future proposals and realizations influenced by those ideas reshaped urban design for years to come.

During the 21st century large urban organisms or urban sections sprung up in the East (China, Korea) and Middle East some seriously reflecting on sustainable city organism (Masdar City). Most of these efforts concentrated on high-rise resolution or mixed high and low rise with high density to provide flexibility and maximize the utilization of open space for public needs. Rarely these efforts concentrated on achieving high density with low-rise resolution in which prime importance will be given to the organizational and functional hierarchy, spatial quality, individuality, and quality of life of residing population.

When compared with Ideal City defined by military fortifications, Grammichele in its own period of design stood apart and provided for the civic, community, and private needs of its population. But 
Grammichele could teach us a lesson, serving as an example of well-designed, low-rise, highdensity, well-organized, functional community with defined functions and spatial hierarchy even in the modern times.

\section{REFERENCES}

[1] More, Thomas \& Sir, Saint, Utopia The Truly Golden Book About the Best Condition of a Commonwealth and About the New Island of Utopia. Renaissance Society of America 2000 Printed in Canada Reprinted by permission of the author from More's Utopia (Hammersmith: HarperCollins Academic, @ 1991 Dominic Baker-Smith.

[2] Campanella, Tommaso, La Citta del Sole: Dialogo Poetico. The City of the Sun: A Poetical Dialogue translated with introduction and notes by Daniel J. Donno University of California Press 1982 reprinted and translated from the original manuscript version written by Campanella in 1602 .

[3] Barzun, Jacques, From Dawn to Decadence 500 Years of Western Cultural Life 1500 to Present, Perennial. An imprint of Harper Collins Publishers: New York, p. 117, 2001.

[4] Filarete (Antonio Averulino) Treatise on Architecture, Book VI, Folio 43R, reprinted and translated with an introduction by John Spencer, New Haven and London Yale University Press, 1965.

[5] Cataneo, Pietro, I Quattro Primi Libri di Architettura 1567, pp. 12-14, Con privilegio del fommo Pontefice per anni X. \& dell'illuftriffima Signoria di Vinegia per anni XV.

[6] Scamozzi, Vincenzo, Dell'idea della Architettura Universale 1615 Publicata dell cura di Stefano Ticozzie dell Engegnere Luigi Masieri. Milano Coi Tipi di Borroni E Scotti Successori a Vincenzo Ferrario MDCCCXXXVIII (1835).

[7] Rosenau, Helen, The Ideal City In Its Architectural Evolution. Routledge and Kegan Paul: London, 1959.

[8] Vitruvius, De Architettura. Book I, VI, wind direction and city orientation, First published by Fra Giovanni Sulpitius 1486, Reprinted (translated) by Cambridge University Press, Cambridge, pp. 53-67, 1999.

[9] Dufour, L. \& Raymond, H., Citta Ideale, Citta Reale: Avola e Grammichele. Domenico San Filippo Editore: Catania, 1994.

[10] Boscarino, Salvatore, Sicilia Barocca architettura e citta 1610 - 1760, Officina Edizioni terza edizione: Roma, pp. 70-79, 1997.

[11] Giuffre, Maria, Utopie Urbane Nella Sicilia dell 700's Quaderno n. 8-9 Dicembre, pp. 52-129, 1966, Universita degli Studi di Palermo, Facolta di Architettura di Elementi di Architettura e Rilievo del Monumenti.

[12] Giuffre, Maria, Miti e Ralata dell'Urnabistica Siciliana, Palermo: Lo monaco, 1969.

[13] Boscarino, Salvatore, Sicilia Barocca architettura e citta 1610 - 1760, Officina Edizioni terza edizione: Roma, pp. 85-88, 1997.

[14] Gianformaggio, Giovanni, Occhiola. Catania Cav. Niccolo Giannotta, Editore, 1928.

[15] Serlio, Sebastiano, Tercero y quarto libro de Architectura. Faculdade de Letras da Universidade de Lisboa Libro Tercero XLIIII, p. 87. Baltazare Peruzzi drew the plan first, followed by reconstruction drawing by Pirro Ligorio (1554). But it was Sebastiano Serlio who published the plan in the Third and Fourth Book of Architecture (1573).

[16] Gianformaggio, Giovanni, Occhiola. Catania Cav. Niccolo Giannotta Editore 1928. Part of the text was reprinted in the book A cura di Aurelio cantone La Citta Plurale. Racolta di materiali e saggi su Grammichele in occasione del Concorso di Progettazione per la redifinizione architettonica della Piazza Carlo Maria Carafa. Comune di Grammichele con l'alto 
patrocinio del Ministero per I eni Culturali e Ambientali. the plan was imagined and conceived by the prince himself, and was cut into a piece of slate by brother Michele da Ferla from the order of Minori Osservanti, an esteemed architect who as well traced the plan on land - (my translation).

[17] Guidoni, Marino Angela. Grammichele, Tratto da Storia dell'Arte Italiana, Vol. VIII. Inchieste sui Centri Minori. Torino Finaudi 1980. The text was reprinted in the book A cura di Aurelio cantone La Citta Plurale. Racolta di materiali e saggi su Grammichele in occasione del Concorso di Progettazione per la redifinizione architettonica della Piazza Carlo Maria Carafa. Comune di Grammichele con l'alto patrocinio del Ministero per I eni Culturali e Ambientali.

[18] Gianformaggio, Giovanni, Occhiola. Catania Cav. Niccolo Giannotta Editore 1928. Part of the text was reprinted in the book A cura di Aurelio cantone La Citta Plurale. Racolta di materiali e saggi su Grammichele in occasione del Concorso di Progettazione per la redifinizione architettonica della Piazza Carlo Maria Carafa. Comune di Grammichele con l'alto patrocinio del Ministero per I eni Culturali e Ambientali.

[19] Le Corbusier, Towards An Architecture, Vers Une Architecture Les Editions G. Cres Et Cte, first printed in French, pp. 125-127, 1921. 